\title{
Economic Aspects of Precision Agriculture Systems
}

\author{
Ludmila Pánková ${ }^{1}$, Renata Aulová1, Jan Jarolímek ${ }^{2}$ \\ ${ }^{1}$ Department of Economics, Faculty of Economics and Management, Czech University of Life Sciences \\ Prague, Czech Republic \\ ${ }^{2}$ Department of Information Technologies, Faculty of Economics and Management, Czech University of Life \\ Sciences Prague, Czech Republic
}

\begin{abstract}
The paper deals with an economic assessment of impacts of precision agriculture (PA) on crop production economy. Based on a questionnaire survey and a FADN agricultural product expense-to-revenue ratio survey, it analyses a set of agricultural businesses the structure of which essentially copies the composition of business forms in the Czech Republic's agricultural sector. The economic assessment applies economic analysis methods based on cost calculations and a calculation formula that considers the commodity and species production structure. Based on an analysis of a number of scientific studies, it determines specific cost savings and makes a quantification of the effect of precision agriculture techniques on costs. In all the production areas, the greatest effect caused by application of precision agriculture techniques was quantified for winter wheat. Conversely, the lowest financial effects are shown in the analysed production areas for spring wheat. We also identified differences in the cost savings between spring and winter barley; the greater savings occur for winter barley. Financial effects in the form of reduced production costs were also found for other analysed crops cultivated by the businesses studied. The financial savings for the pea plant are almost comparable to those for winter barley. The greatest financial savings were achieved for sugar beet.
\end{abstract}

\section{Keywords}

Precision agriculture, economic savings, techniques, work operations, costs, calculation formula.

Pánková, L., Aulová, R. and Jarolímek, J. (2020) "Economic Aspects of Precision Agriculture Systems", AGRIS on-line Papers in Economics and Informatics, Vol. 12, No. 3, pp. 59-67. ISSN 1804-1930. DOI 10.7160/aol.2020.120306.

\section{Introduction}

Precision agriculture can be characterised as a solution leading to reduction in agrochemical inputs and reduction of adverse environmental impacts of agriculture, where the basic benefits for the farmer are seen in the economic area (reduced costs by means of controlled application of agricultural inputs), in increased yields (targeted management of field variability) and, last but not least, a favourable environmental impact in the sense of precise application of agrochemical products (Kendall et al., 2017).

Precision agriculture is one of the ways to increase competitiveness of Czech agriculture while also better combining application of scientific results and techniques directly in agricultural businesses. It thus helps eliminate the weaknesses of Czech agriculture (reduction of production costs in particular) and contributes to increasing profitability/competitiveness of businesses.

The investment and capital costs of machinery used for precision agriculture are very different (Robertson et al., 2008; Vogt, 2017). Some technologies (e.g. auto-steer or yield mapping) are usually a standard equipment of new machines and mean very low capital costs. Some new technologies (e.g. GreenSeeker technology, camera spraying technologies) are associated with higher investment.

The precision agriculture technique brings a number of favourable effects in practice. They contribute, for example, to reduced soil compaction thanks to targeted movement of machinery on plots and more efficient traffic control methods, and bring a saving of time and costs expended on individual work operations. In summary, the techniques in question also contribute to increased labour productivity. The benefits 
resulting from using of PA technologies are derived from many key drivers (Vogt, 2017; Calegari et al., 2013; West and Kovacs, 2017): capital and annual operating costs associated with acquiringthe technology, impact of the technology on labour demand, impact on yield, product quality, cost savings, environmental benefits etc. Nevertheless Robertson et al. (2008) argue, that the profitability of PA and benefits from PA technologies varies from farm to farm, in line with farmer preferences and circumstances.

The literature survey indicates that precision agriculture, as a form of application of modern technologies and approaches, can be one of the paths to increased profitability of agricultural production. Moreover, the literature says that precision agriculture can be seen as a management method that is more environmentally friendly (due to not only targeted application of fertilisers or plant protection products but also the soil management method and control of machinery traffic on plots to increase soil quality, reduce soil compaction, etc.). A number of studies and research papers from various countries point out the positive impacts of precision agriculture (e.g., Godwin, 2002, 2015; Cassman, 1999, and others).

Many experts define the benefits of precision agriculture techniques in not only quantitative but also qualitative terms. For example, Cordesses et al. (2000), Dunn et al. (2006), Debain et al. (2000), Han et al. (2004), Kingwell (2011), Stoll and Kutzbach (2000) sum up the following general benefits of using a guidance system, for example:

- $\quad$ reduced driver fatigue: guidance systems reduce the efforts associated with maintaining precise paths;

- $\quad$ increased yields;

- reduced costs of work operations: accuracy is increased by reducing "skipping" (omissions) and "doubling" (repeated applications - overlaps) between adjacent rows in the field;

- $\quad$ increased productivity: higher operating speeds are possible;

- better quality: the driver can focus attention elsewhere to increase quality;

- improved safety;

- lower adverse environmental impact (reduced frequency of machine crossings, reduced soil compaction);

- ability to work at night and under reduced visibility.
Buchtel (2016) defines the impacts of precision agriculture as follows:

- time savings: evident in a number of work operations, particularly in harvesting, soil preparation and spraying;

- savings in labour costs (harvesting, soil preparation, spraying, sowing, fertilising), equipment costs, chemical plant protection products, seed stock, fertilisers, fuels;

- $\quad$ increased crop yields.

The benefits of precision agriculture are also confirmed by Kviz et al. (2014), who define savings due to use of RTK (Real Time Kinematic) based guidance systems, in the sense of time savings from the number of field operations in a season, or reduction in machinery crossings compared to the conventional system. The authors say that better accuracy of machinery with guidance systems in fields could help achieve energy and material savings and, to some extent, reduce machinery traffic in fields, thus improving soil conditions.

The present paper follows up on the research of the above authors and attempts a verification of the expected economic savings and their quantification.

\section{Materials and methods}

The primary objective of the present paper is to provide the simulation of precision agriculture (PA) impact on crop production economy. The primary objective is achieved by means of secondary goals:

- Description of techniques and work operations in PA;

- Study of structure of agricultural crop production costs;

- Simulation of effects of selected techniques PA on production economy.

The background data for the present paper are based on a questionnaire survey as well as a FADN agricultural product expense-to-revenue ratio survey in 2015 (ÚZEI, 2015). The representative set group consisted of 14 agricultural entities applying precision agriculture techniques in practice. The analysed set of businesses can be divided by business structure into natural persons and legal entities. Natural person businesses made up $14.3 \%$ of the agricultural entities analysed, and legal entities comprised $85.7 \%$. The structure of the set of businesses therefore essentially copies the composition of agricultural business forms in the Czech Republic. 
Among the legal entities, the most common forms were joint stock companies and limited liability companies (29\% each). Another category of businesses were cooperatives $(21.4 \%)$. The least represented category comprised other legal forms, specifically limited partnerships (7\%).

In terms of representation of analysed agricultural entities in different agricultural production areas, it can be said that the analysed group of businesses were mostly active in the sugar beet production area, followed by the potato and maize production areas.

The data obtained in the questionnaire survey was used for the crops specification representing the analyzed group of companies on which the simulation was demonstrated. Based on the companies unavailability of detailed cost structure related to PA technology, the simulation of production costs was calculated by using agricultural commodities costing published in the FADN database, with the rate of cost savings determined by Buchtel (2016).

The economic assessment applies economic analysis methods based on cost calculations and a calculation formula using the FADN dataset 2015. The calculation formula is based on the methodology of ÚZEI (2015), applied in studying the expense-to-revenue ratio of agricultural commodity production. The calculation formula classifies agricultural commodity production costs in the following structure:

seed stock (own and purchased)

+ fertilisers (own and purchased)

+ chemical protection products

+ other direct materials

$=$ direct material costs

+ other direct material costs

+ wage and personnel costs (direct, auxiliary activities)

+ depreciation

+ costs of auxiliary activities

+ production overheads

+ administrative overheads

$=$ total costs

In studying the cost effect of precision agriculture techniques and economic effects following from that, this paper applies not only a questionnaire survey but also a literature survey and the structure of operating costs studied in the Czech Republic, based on the commodity and type structure. In terms of commodities, the assessment (depending on the structure of sowing procedures of the analysed businesses) included cereals (winter wheat, spring wheat, winter barley, spring barley), rape as the oil crop and other crops such as pea and sugar beet.

Taking the average structure of total costs expended per hectare of selected agricultural crops (based on results of ÚZEI, 2015) as the starting point, the average structure of the total costs consists of:

\section{- Direct material costs \\ - $\quad$ Personnel costs \\ - Other direct costs including services \\ - Other costs}

The direct material inputs are composed of the cost items for seed stock (purchased and own), fertilisers (purchased and own), plant protection products, and other direct materials (such as packaging).

The personnel cost structure comprises costs of employees including levies for social and health insurance. The other direct costs include external services, utilities, fuels, insurance premiums, rent, etc. The other cost category comprises the following sum of items: depreciation of longterm tangible and intangible assets, production and administrative overheads, and costs of auxiliary activities (e.g., costs of own machinery, repairs and maintenance).

Based on the results of Buchtel (2016), we were able to work with specific percentages of cost savings. This savings can be specified in direct cost (seed stock $1.9 \%$, fertilisers $2.61 \%$, plant protection products $6.21 \%$ ), personal costs $(3.47 \%)$ and other direct cost and services (3.4\%). By means of the figures shown in the study, we can simulate the effect of precision agriculture techniques in the area of costs by using the FADN dataset.

\section{Results and discussion}

The production cost structure is primarily assessed based on data from ÚZEI (2015). As shown in Figure 1, the total cost structure for cereal crops comprises $37 \%$ of direct material costs, and a similar proportion is for the other costs (sum of depreciation, overheads, etc.); the personnel costs are $17 \%$ of the total costs. Less than $10 \%$ is drawn by services along with the other direct costs. The differences between the selected representatives of cereals, i.e., winter and spring wheat and winter and spring barley, are not very significant. The direct material costs are the highest for winter 


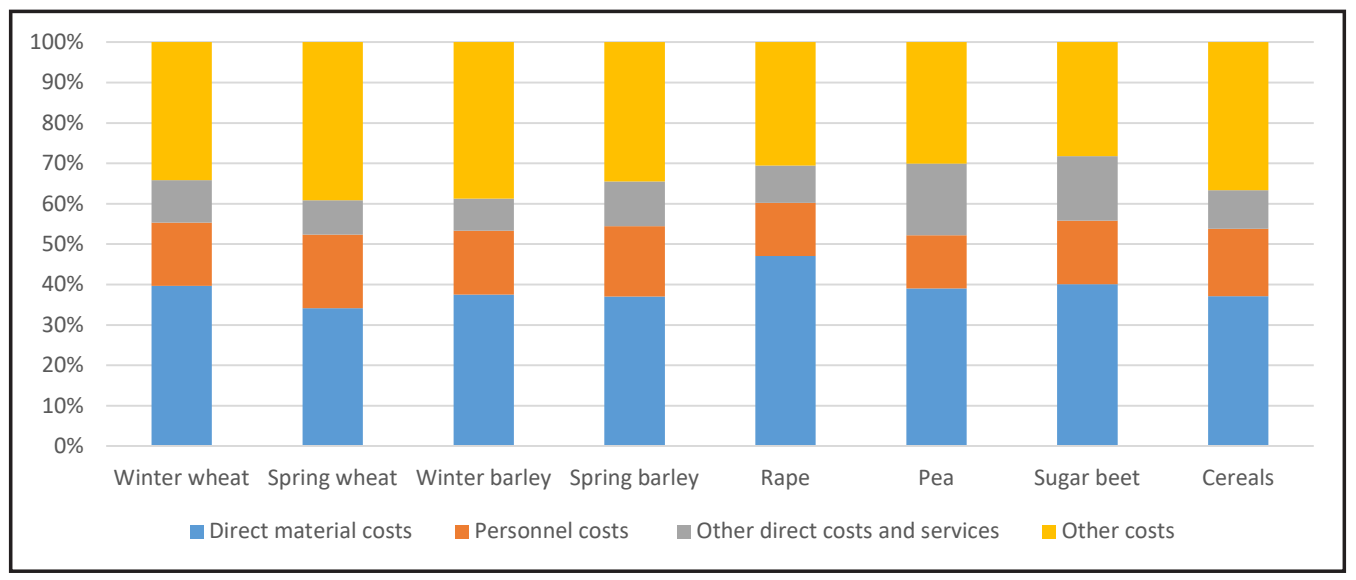

Source: ÚZEI (2015) and own calculations

Figure 1: Average structure of production costs of selected agricultural crops in the CR.

wheat $5.5 \%$ higher on average compared to spring wheat and $2.2 \%$ and $2.6 \%$ higher compared to winter barley and spring barley, respectively). The direct material costs of rape, pea and sugar beet exceed the percentage of the total costs by up to $10 \%$ compared to the cereals (rapeseed the most).

The analysis of the trends based on the ÚZEI database (2015) for costs per hectare of the agricultural crops assessed shows that the production areas partly influence not only the amount of total costs expended per hectare of crop but also the type structure of the operating costs. Whilst the total costs per hectare of all the studied crops in the potato production area are lower, their type structure shows higher direct material costs (by up to $4 \%$ ) in comparison with the maize and beet production area.

The application of precision agriculture techniques is very tightly linked with the direct costs, which comprise the costs of seed stock, fertilisers and chemical protection products. This link can be observed, e.g., in the reduced consumption of direct material input, targeted application and precise dosage. In line with that, fuel consumption, labour costs, etc., also decrease. According to the ÚZEI survey, the direct material costs also include so-called other direct material costs, but they are almost negligible in terms of the total costs per hectare (e.g., their share is $0.75-2.3 \%$ of the total costs for cereals, i.e., CZK 177-556 per hectare depending on the crop and the production area).

Figures 2 and 3 show the structure of the direct material costs by crop and production area. The structure of the direct material costs of cereals is dominated by costs of fertilisers (Figure 2) for all the agricultural production areas analysed.
Their share in the total material costs is the highest for winter wheat, for which it is over $50 \%$ of the direct material costs in the maize and beet production area. Similarly, rape too (Figure 3) shows a high share of fertiliser costs (48-50\% depending on production area). The commodities of sugar beet and pea in the maize and beet production area show a share of costs of chemical protection products higher than that of fertiliser costs. However, that is not the case in the potato production area. Among the analysed commodities, pea has the highest share of costs of seed stock (35-48\% of the material costs). Rape has the lowest costs of seed stock (as a share of material costs); the share of these costs in the direct material costs does not exceed $10.5 \%$ in either production area.

A number of other facts indicated by expert studies cannot be omitted in the context of precision agriculture and in connection with the analysed structure of material costs. They confirm clearly that the size of the material costs is related not only to the price of material but also its consumption, which can be influenced significantly by the quality and method of performance of the component agrotechnical work operations. They include, for example, soil treatment and soil preparation before sowing. For example, Scarlett et al. (1997) cite the saving of EUR 14/ha in the case of following up on the quality of soil treatment and adjustment of sowing quantity based on the current condition. In another report, they say that the sowing quantity is considerably influenced by the quality of the seedbed (it can be reduced greatly without any loss of yield), and they quantify the potential for sowing cost saving at up to $70 \%$. On the other hand, similar results (such high savings) can only be achieved with difficulty in actual practice. Malik et al. (1985) and Marchenko (1989) 


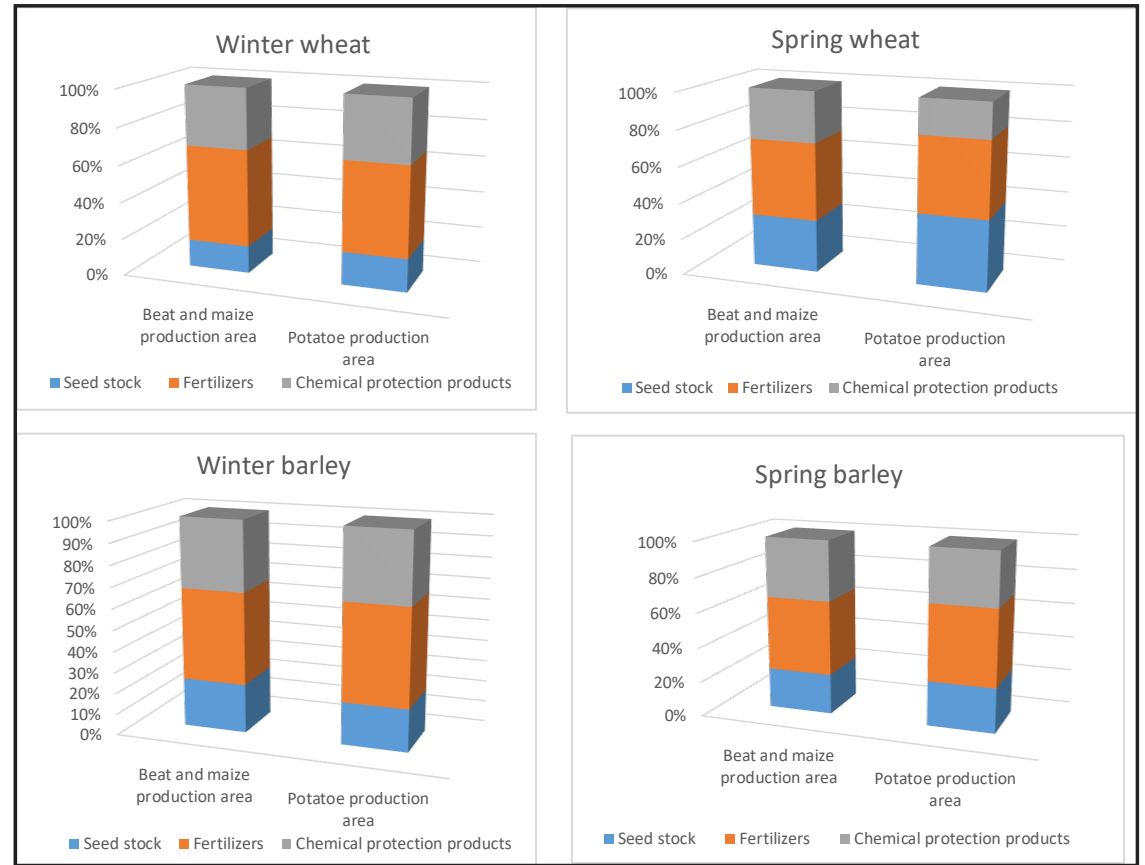

Source: ÚZEI (2015) and own calculations

Figure 2: Direct material costs of selected cereal crops in the CR.

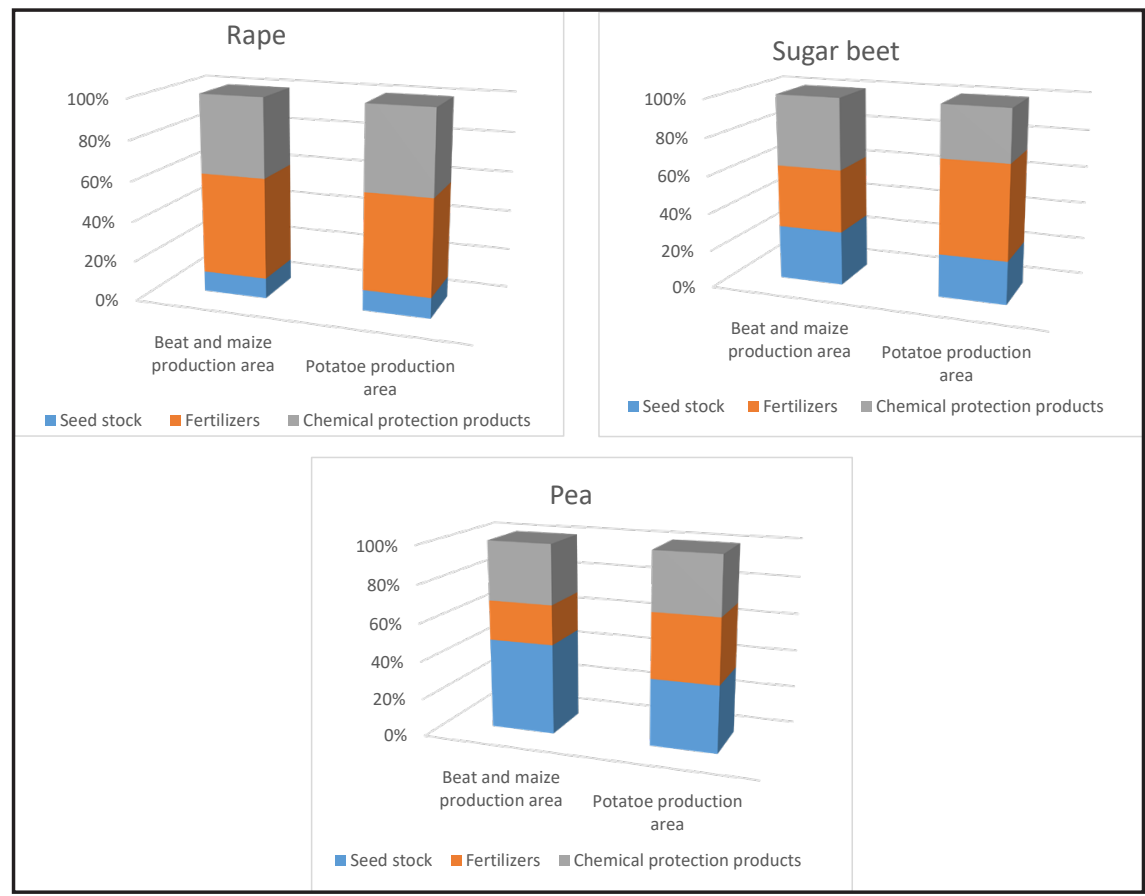

Source: ÚZEI (2015) and own calculations

Figure 3: Direct material costs of other studied crops.

document the relationship between cloddiness of the soil surface and the seedbed, where the sowing quantity increases with the cloddiness. At the same time, it is common practice that the tractor driver checks the preparation quality and cloddiness visually on the surface of the treated soil, not by mesh analysis (soil sifting in order to determine cloddiness), which ultimately results in repeated crossings (Scarlett et al., 1997). Variable sowing depth is still not used in common precision agriculture practice either.

The primary objective of variable soil treatment is to assure smooth transition of treatment depth 
and intensity, soil re-compaction, etc., depending on the soil block conditions. Variable sowing systems are clearly linked to precision sowing for slim-row crops. With cereals and rape in particular, the array pitch between plants have to be observed precisely to optimise the space for each plant and eliminate intra-species competition, and the possibility to vary the sowing quantity has to be enabled in relation to the macro and micro variability of the plot. The possibility to vary the sowing quantity during a working trip opens up a new room for reducing sowing quantities, not to be applied overall but in relation to the current moisture conditions and plot variability (Brant et al., 2016).

The cost saving calculation based on Buchtel (2016) enables us to quantify the total average cost saving in precision agriculture. His research indicates that the greatest cost savings occur in pesticide costs, followed by labour cost savings. Cost savings were also proven for fuels, fertilisers and seed stock.

It holds for the maize and beet production areas that the greatest effect caused by application of precision agriculture techniques is quantified for winter wheat, being CZK 659/ha; the same results are achieved in the potato production area. Conversely, the lowest financial effects are shown in the analysed production areas for spring wheat. The difference in the cost savings for winter barley and spring barley in the beet and maize production areas is CZK 30/ha (higher savings achieved for spring barley); the difference is negligible in the potato production area (only CZK 11/ha, with higher savings for winter barley). The reason for these equalised results are probably the fact arising from the UZZEI data (ÚZEI, 2015) that the production costs in the potato production area are almost comparable to that of spring barley. Financial effects in the form of reduced production costs were also found for other analysed crops cultivated by the businesses studied. The savings for winter rape are CZK 890-969/ha depending on the production area. The financial savings for the pea plant are almost comparable to those for winter barley. The greatest financial savings were achieved for sugar beet.

It follows from Figures 4 and 5 that the cost structure is dominated by the economic benefits of chemical plant protection costs. Conversely, the calculated savings are the lowest for seed stock, which is due to the share of the seed stock costs in the total costs. In the case of wage costs, it has to be noted that the resulting financial effect (cost saving) is the sum of all work operations performed as part of the cultivation technique.

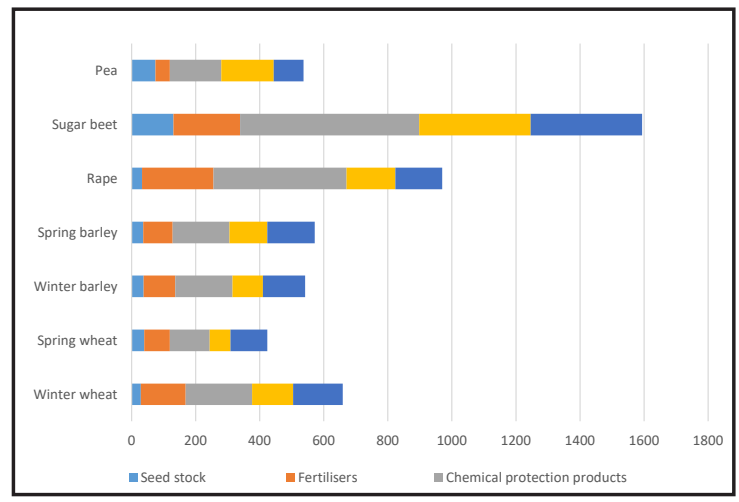

Source: own calculations

Figure 4: Cost savings for selected crops applying PA techniques in maize and beet production area.

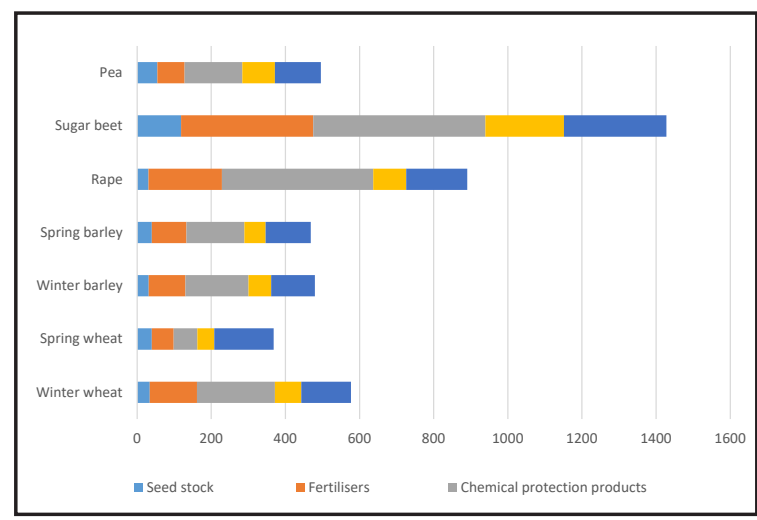

Source: own calculations

Figure 5: Cost savings for selected crops applying PA techniques in potato production area.

Application of precision agriculture techniques is related not only to savings on the cost side but, typically, also another effect in the form of increased natural production per unit of area and the related financial result in the form of revenues. However, that will be the subject matter of our further research.

Speaking, for example, about the average size of the studied legal entity businesses included in this representative survey (i.e., 3,567 hectares of farmland), the size of potential savings for each crop can be estimated when considering the tillage percentage and the existing crop area structure (see Table 1). The calculation of the theoretical savings is based on the assumption that cereal crops make up $54 \%$ of the crop succession for the businesses studied. 


\begin{tabular}{|l|c|c|}
\hline \multirow{2}{*}{$\begin{array}{l}\text { Crop/ } \\
\text { Production area }\end{array}$} & \multicolumn{2}{|c|}{$\begin{array}{c}\text { Estimate of theoretical cost savings } \\
\text { (in thousands of CZK) }\end{array}$} \\
\cline { 2 - 3 } & $\begin{array}{c}\text { Beet and maize } \\
\text { production area }\end{array}$ & $\begin{array}{c}\text { Potato production } \\
\text { area }\end{array}$ \\
\hline Cereals & 933.6 & 804.3 \\
\hline Rape & 518.7 & 476.3 \\
\hline Pea & 33.8 & 31.2 \\
\hline Sugar beet & 100.3 & 89.9 \\
\hline
\end{tabular}

Source: own calculation

Table 1: Estimate of theoretical cost savings for selected crops (given average business size in representative survey).

Since contemporary practice shows varying degrees and levels of practical application of precision agriculture techniques, an assessment of impacts of techniques applied on the business economy of the agricultural entities will be the subject matter of our further study.

\section{Conclusion}

The precision agriculture technique brings a number of favourable effects in practice. They contribute, for example, to reduced soil compaction thanks to targeted movement of machinery on plots and more efficient traffic control methods, and bring a saving of time and costs expended on individual work operations. In summary, the techniques in question also contribute to increased labour productivity. Precision agriculture techniques offer the Czech farmer a considerable potential not only in agricultural production but also in the area of methodology, linked to data analysis and processing. Precision agriculture principles help develop an innovative approach to the traditional sector of the national economy by application of modern technologies while respecting the heterogeneity of the soil environment.

The results of the study clearly indicate a favourable practical effect of precision agriculture. It is manifested at several levels, both in the environmental and landscape areas and in the economic area (cost effect).

The primary production factor - soil - is thus perceived much more sensitively in precision agriculture, with respect, e.g., to nutrient supply to soil, necessity of machinery travel on plots in an effort to reduce soil compaction, etc. Since the structure of the agricultural commodity production costs includes a high share of costs of chemical plant protection, their economically effective expenditure is a relatively important aspect of economic prosperity of businesses.

The results obtained enable us to identify the dominant cost items that have a significant influence on the economy of agricultural commodity production. For all the crops studied, these dominant items among the cost types are, above all, the direct material inputs, the shares of which are differentiated depending on the commodity.

The economic benefit of precision agriculture is evident based on the results obtained. It is manifested in all the production areas analysed, and the effect of financial savings in production costs can be additionally enhanced, on the other hand, by the effects of precision agriculture on the revenue side, as indicated by a number of studies conducted in the area.

\section{Corresponding authors}

Ing. Ludmila Pánková, Ph.D.

Department of Economicss, Faculty of Economics and Management

Czech University of Life Sciences Prague, Kamycka 129, Prague 6, 16521, Czech Republic

Phone: +420 224382 283,E-mail: pankoval@pef.czu.cz

\section{References}

[1] Brant, V., Kroulík, M., Zábranský, P. and Škeř, M. . (2016) "Nižší výsevky a zonální aplikace hnojiv při pěstování obilnin jako základ precizního zemědělství“, Agro journal. [Online]. Available: https://www.agrojournal.cz/clanky/nizsi-vysevky-a-zonalni-aplikace-hnojiv-pri-pestovani-obilninjako-zaklad-precizniho-zemedelstvi-135 [Accessed: 12. Dec. 2019]. (In Czech).

[2] Buchtel, F. (2016) "Vyhodnocení ekonomické efektivity systému precizního zemědělství v podmínkách vybrané farmy v ČR“, Bachelor thesis, University of South Bohemia in České Budějovice, Faculty of Economics, tutor: Antonín Dolan. (In Czech).

[3] Calegari, F., Tassi, D. and Vincini, M. (2013) "Economic and environmental benefits of using a spray control system for the distribution of pesticides“, Journal of Agricultural Engineering, Vol. 44, No. 2s, pp. 163-165. E-ISSN 2239-6268. DOI 10.4081/jae.2013.274. 
[4] Cassman, K. G. (1999) "Ecological intensification of cereal production systems: Yield potential, soil quality, and precision agriculture", Proceedings of the National Academy of Science of the United States of America, Vol. 96, No. 11, p. 5952-5959. E-ISSN 1091-6490. DOI 10.1073/pnas.96.11.5952.

[5] Cordesses, L., Cariou, C. and Berducat, M. (2000) "Combine harvester control using Real Time Kinematic GPS“, Precision Agriculture, Vol. 2, No. 2, pp. 147-161. E-ISSN 1573-1618, ISSN 1385-2256. DOI 10.1023/A:1011473630247.

[6] Debain, C., Chateau, T., Berducat, M., Martinet, P. and Bonton P. (2000) "A guidance-assistance system for agricultural vehicles“, Computers and Electronics in Agriculture, Vol. 25, No. 1-2, pp. 29-51. ISSN 0168-1699. DOI 10.1016/S0168-1699(99)00054-X.

[7] Dunn, P. K., Powierski, A. P. and Hill, R. (2006) "Statistical evaluation of data from tractor guidance systems“, Precision Agriculture, Vol. 7, No. 3, pp. 179-192. E-ISSN 1573-1618, ISSN 1385-2256. DOI 10.1007/s11119-006-9007-8.

[8] Godwin, R., Earl, R., Taylor, J. C., Wood, G. A., Bradley, R. I., Welsh, J. P., Richards, T. and Blackmore, B. S. (2002) "Precision farming of cereal crops: A five-year experiment to develop management guidelines“, AHDB Cereals \& Oilseeds [Online]. Available: https://cereals.ahdb.org. uk/media/288142/pr267-final-project-report.pdf [Accessed: 13 Dec. 2019].

[9] Godwin, R. (2015) "Precision farming“, INGENIA online, No. 64. [Online]. Available: http://www.ingenia.org.uk/Content/ingenia/issues/issue64/godwin.pdf [Accessed: 13 Dec. 2019].

[10] Han, S., Zhang, Q., Ni, B. and Reid, J. F. (2004) "A guidance directrix approach to vision-based vehicle guidance systems“, Computers and Electronics in Agriculture, Vol. 43, pp. 179-195. ISSN 0168-1699. DOI 10.1016/j.compag.2004.01.007.

[11] Heiniger, R. W. and Meijer, A. J. (2000) "Why variable rate application of lime has increased grower profits and acceptance of precision agriculture in the southeast", In SO: Proceedings of the $5^{\text {th }}$ International Conference on Precision Agriculture,Bloomington, Minnesota USA,16. - 19. July, 2000. publ 2001; pp. 1-17. Madison, USA: American Society of Agronomy.

[12] Kendall, H. et al. (2017) "Precision Agriculture in China: Exploring Awareness, Understanding, Attitudes and Perceptions of Agricultural Experts and End-Users in China", Advances in Animal Biosciences: Precision Agriculture (ECPA), Vol. 8, No. 2. p. 703-707. E- ISSN 2040-4719, ISSN 2040-4700. DOI 10.1017/S2040470017001066.

[13] Kingwell, R. (2011) "The whole-farm benefits of controlled traffic farming: An Australian appraisal“, Agricultural systems, Vol. 104, No. 7, pp. 513-521. ISSN 0308521x. DOI 10.1016/j.agsy.2011.04.001.

[14] Kviz, Z., Kroulik, M. and Chyba, J. (2014) "Evaluation of Machinery Guidance Systems Concerning Pass-to-Pass Accuracy as a Tool for More Efficient Plant Production in Fields and Soil Damage Reduction“, Plant, Soil and Environment, Vol. 60, No. 1, pp. 36-42. E-ISSN 1805-9368. DOI 10.17221/622/2012-PSE.

[15] Malik, R. S., Jhorar, B. S. and Dahiya, I. S. (1985) "Influence of seedbed tilth on emergence and root and shoot growth of seedling of some crops“, Experimental Agriculture, Vol. 21, No. 1, pp. 59-65. E-ISSN 1469-4441, ISSN 0014-4797. DOI 10.1017/S0014479700012254.

[16] Marchenko, O. S. (1989) "Optimising soil cultivation and seedbed preparation parameters referring to soilconditions", Land and Water Use, Proceedings of the 11th International Congress on Agricultural Engineering, Dublin, (Dodd V. A; Grace P. M.), Balkema, Rotterdam, Vol. 2, pp. 1507-1517. ISBN 9061919770.

[17] Robertson, M., Carberry, P. and Brennan, L. (2008) "Economic benefits of precision agriculture. Case studies from Australian grain farms", Grain Researd and Development Corporatio, 14 Feb, 2008 [Online]. Available: https://grdc.com.au/resources-and-publications/grdc-update-papers/tabcontent/grdc-update-papers/2008/02/economic-benefits-of-precision-agriculture-case-studies-fromaustralian-grain-farms [Accessed: 10 Nov. 2019]. 
[18] Scarlett, A. J., Lowec, J. C. and Semple, D. A. (1997) "Precision tillage: in-field, real-time control of seedbed quality", Precision Agriculture, Proceedings of the 1st European Conference on Precision Agriculture, BIOS Scientific Publishers Ltd, 1997, p. 503 - 510. ISBN-13 978-1859962367.

[19] Sparovek, G. and Schnug, E. (2001) "Soil tillage and precision agriculture - A theoretical case study for soil erosion control in Brazilian sugar cane production“, Soil \& Tillage Research, Vol. 61, No. 1-2, p. 47-54. ISSN 0167-1987. DOI 10.1016/S0167-1987(01)00189-1.

[20] Stoll, A. and Kutzbach, H. D. (2000) "Guidance of a forage harvester with GPS“, Precision Agriculture, Vol. 2, No. 3, pp. 281-291. E-ISSN 1573-1618, ISSN 1385-2256. DOI 10.1023/A:1011842907397.

[21] Vogt, S. (2017) "The economics of precision agriculture“, Grain Researd and Development Corporatio, 07 Feb, 2017 [Online]. Available: https:/grdc.com.au/resources-and-publications/grdcupdate-papers/tab-content/grdc-update-papers/2017/02/the-economics-of-precision-agriculture [Accessed: 10 Nov. 2019].

[22] UZEI (2015) "Dataset FADN", [Online]. Available: UZEI: http://www.vsbox.cz/fadn/ [Accessed: 20. Feb. 2019].

[23] West, G. H. and Kovacs, K. (2017) "Addressing Groundwater Declines with Precision Agriculture: An Economic Comparison of Monitoring Methods for Variable-Rate Irrigation", Water, Vol. 9, No. 1. ISSN 2073-4441. DOI 10.3390/w9010028. 